\title{
Effects of supplementing ragi \\ (Eleusine coracana) diets with lysine or leaf protein on the growth and nitrogen metabolism of children
}

\author{
By T. R. DORAISWAMY, NARENDRA SINGH AND V. A. DANIEL \\ Central Food Technological Research Institute, Mysore, India
}

(Received 12 November I968-Accepted 24 March 1969)

\begin{abstract}
I. Diets based on ragi (Eleusine coracana) (I) were supplemented with L-lysine monohydrochloride (2) to provide $0.50 \mathrm{~g}$ additional lysine per day, or with lucerne leaf protein (3) to provide the same amount of lysine as 2 , or with sesame flour (4) to provide the same amount of protein as 3 . The effects of such supplementation on the growth and nutritional status of twenty children fed on each diet were studied in a feeding trial lasting for 6 months. Nitrogen retention and apparent digestibility of the diets were also studied at one stage during the feeding trials.

2. Supplementing ragi diets with any of the materials brought about improvement in all nutritional responses, i.e. height, weight, general nutritional status, apparent digestibility and $\mathrm{N}$ retention. The diet supplemented with leaf protein led to the greatest response in growth, as measured by increase in height and weight, followed by those supplemented with lysine and sesame flour in that order.

3. The apparent digestibility of the lysine-supplemented diet was lower than those of the diets supplemented with leaf protein and sesame flour.

4. The differences in $\mathrm{N}$ retention between the children on the three supplemented diets were not significant.

5. The most important observations were that, although lysine as a sole supplement improved the quality of ragi diets, the leaf protein was superior to it because it improved the quality and increased the content of protein in the diet, and that the sesame flour, in spite of increasing the protein content, did not provide adequate lysine.
\end{abstract}

Cereals, including the millets, are the major source of protein in the diet of the people of Asia and Africa. The protein quality of such grains has been shown to be greatly improved by supplementation with the limiting amino acids, singly or in mixtures (see review by Venkat Rao, Joseph, Swaminathan \& Parpia, 1964). Ragi (Eleusine coracana), a widely cultivated millet in South India, is a major ingredient of the common diets in the region. This millet is reported to be deficient in lysine (Balasubramanian, Ramachandran, Viswanatha \& De, 1957), which suggests the possibility of improving the quality of diets based on ragi by supplementing them with lysine.

A recent review of the work on leaf protein over the last three decades has focused attention on the possibility of producing nutritionally adequate, protein-rich materials directly from green vegetation (Pirie, 1966). Work in this laboratory has further shown that the lysine content of leaf protein made from lucerne (Medicago sativa) is adequate for rats (Shurpalekar, Singh \& Sunderavalli, I966), and also suggested the possibility of greatly increasing the yield of food protein from the land by the production of edible protein from leaves (Singh, 1966). This background of information suggested that the lysine-deficient diets could be improved by supplements of leaf protein.

Studies, were therefore undertaken to investigate the effects of supplementing the 
common South Indian diets based on ragi, with L-lysine or with leaf protein made from lucerne on the growth, general nutritional status and nitrogen metabolism in children; the results are now presented.

\section{MATERIALS AND METHODS}

The leaf protein was produced from successive $2 \mathrm{I}$-day-old regrowths of lucerne by means of a batch extractor (Davys \& Pirie, 1963); in general, the method outlined by Morrison \& Pirie (1961) was followed. The wet cake of leaf protein was granulated and air-dried in a through-flow oven at $40-60^{\circ}$, milled and passed through a 9o-mesh sieve before use.

A batch of sesame seeds, purchased locally, was passed through an oil-expeller to give the low-fat sesame flour. The proximate composition and lysine content of the leaf protein and sesame flour are shown in Table 1 .

Experimental diets and feeding schedule. The basal diet, having ingredients similar to those habitually consumed by the children, was taken as the control diet and the

Table I. Proximate composition and lysine content of leaf protein and and sesame flour

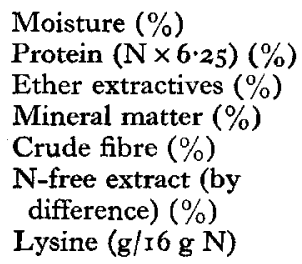

\section{Leaf protein}

$\begin{array}{rr}5 & 7 \\ 66 & 42 \\ 10 & 10 \\ 3 & 5 \\ 1 & 2 \\ 15 & 34\end{array}$

$5 \cdot 5$
Sesame flour

7
42
10
5
2
34
$2 \cdot 6$

$2 \cdot 6$

Table 2. Diets given to the control and experimental children

\section{Foodstuff}

Basal diet, common to all the groups:

Ragi (Eleusine coracana)

Pulses, horsegram (Dolichos biflorus)

Vegetables, amaranthus tender, brinjal, calabash, cucumber, cho-cho and onion

Skim-milk powder

Jaggery (palm sugar)

Salt

Condiments and spices, red chillies, coriander seeds, pepper, fenugreek, cumin, garlic and turmeric

Tamarind fruit pulp (Tamarindus indica)

Groundnut oil

Supplement given to different groups:

Group I (basal, control diet), jaggery

Group 2 (lysine supplement), jaggery

$$
\text { sugar }
$$

L-lysine monohydrochloride

Group 3 (leaf-protein supplement), leaf protein (lucerne) jaggery

Group 4 (sesame-flour supplement), low-fat sesame flour
Intake (g/child day) 
supplements were synthetic lysine, leaf protein and sesame flour. The patterns of the control and supplemented diets are shown in Table 2. The jaggery was added to various diets in varying amounts to make them isocaloric. The basal control ragi diet (group I) provided $38.9 \mathrm{~g}$ of protein and $\mathrm{I} \cdot 79 \mathrm{~g}$ of lysine per child per day. Since only half of this dietary protein was digestible (Subrahmanyan, Narayanarao, Ramarao \& Swaminathan, I955) and consequently only half the amount of lysine available for children, the group on the diet supplemented with lysine (group 2) had an added amount of $0.66 \mathrm{~g}$ of L-lysine monohydrochloride (equivalent to $0.5 \mathrm{~g}$ lysine) per child per day to meet the lysine requirements (Nakagawa, Takahashi, Suzuki \& Kobayashi, 1962). The group on the diet supplemented with leaf protein (group 3 ) had I $5 \mathrm{~g}$ of lucerne leaf protein added to provide an amount of lysine similar to that of group 2. The group whose diet was supplemented with sesame flour (group 4 ) had $24 \mathrm{~g}$ of the low-fat sesame flour added to provide an amount of protein similar to that of group 3 . The values of intake of calories (calculated), protein $(\mathrm{N} \times 6.25)$ and lysine per child per day in different groups are presented in Table 3 .

Table 3. Calorie, protein and lysine intake by the children on ragi diets with various supplements, compared with recommended values

(All values per child per day)

$\begin{array}{clccc}\text { Group no. } & \text { Supplement to diet } & \text { Calories (kcal) } & \text { Protein (g) } & \text { Lysine (g) } \\ \text { I } & \text { None (control) } & 1671 & 39 & 1 \cdot 79 \\ 2 & \text { Lysine } & 1673 & 39 & 2 \cdot 29 \\ 3 & \text { Leaf protein } & 1672 & 49 & 2 \cdot 34 \\ 4 & \text { Sesame flour } & 1675 & 49 & 2 \cdot 05 \\ & \text { Recommended value } & 2000^{*} & 54^{*} & 1 \cdot 36 \dagger\end{array}$

* Recommendations of the Indian Council of Medical Research-Nutrition Advisory Committee (ICMR-NAC, 1944).

$\dagger$ Based on requirements of available lysine- $60 \mathrm{mg} / \mathrm{kg}$ body-weight (Nakagawa, Takahasi, Suzuki \& Kobayashi, 1962).

The pattern of three meals, breakfast, lunch and dinner, throughout the trial period of 6 months was as described by Kurien, Narayanarao, Swaminathan \& Subrahmanyan (1960). The lysine was given to each child as a sweetened drink in equal doses at the three meals. The leaf protein or sesame flour was mixed with ragi flour, cooked and served as round balls at the three meals. There was no adverse reaction among the children in accepting the various diets and all of them were equally relished.

Subjects. The studies were carried out in a boarding house in a village near Mysore. Out of the 180 residents, eighty boys between 6 and 12 years old, free from abnormal clinical symptoms and apparent disease, were selected. On the basis of initial height and weight measurements, the children were allotted to four groups by a randomized block design.

Measurements of nutritional response. Measurements of height, weight, haemoglobin and red blood cell (RBC) counts and the assessment of general nutritional status were carried out as described previously (Doraiswamy, Parthasarathy, Tasker, Sankaran, Rajagopalan, Swaminathan, Sreenivasan \& Subrahmanyan, I962). The mean initial values for height, weight, haemoglobin and RBC counts in children of different groups 
are shown in Table 4 . About 3 months after the feeding trial began, six corresponding children Io-I I years old, from each group were selected to determine $\mathrm{N}$ balance and the apparent digestibility of the diets. The mean height and weight of these children at the start of the metabolic study were $13^{\circ} \cdot \mathrm{I} \mathrm{cm}$ and $24.7 \mathrm{~kg}$ respectively. The procedures for feeding and collection of faecal and urinary excretions were those described by Tasker, Doraiswamy, Narayanarao, Swaminathan, Sreenivasan \& Subrahmanyan (1962).

Analyses. For proximate analyses, the standard methods of the Association of Official Agricultural Chemists were followed and $\mathrm{N}$ was determined by the microkjeldahl method. Lysine was estimated microbiologically by the method of BartonWright (1952).

\section{RESULTS AND DISCUSSION}

The mean increase over the initial values with respect to the height, weight, haemoglobin and red blood cell count in the children after 6 months of feeding on the different diets are presented in Table 4 . The increases in all growth and clinical values of the children on the three supplemented diets were significantly greater than those of the children on the control diet. The differences between the results with the supplemented diets were significant with respect to increase in height and weight but not for the haemoglobin and RBC values. The height and weight increases in children on the diets supplemented with leaf protein were significantly greater than in those on the other two supplemented diets. Of the latter, the response to lysine supplementation was greater than that to sesame flour.

The observations on the general nutritional status of children on various diets, assessed according to the Indian Council of Medical Research-Nutritional Advisory Committee schedule (ICMR-NAC, I948) are presented in Table 5. The chi-square test was applied to determine the differences, if any. Although the general nutritional status of the children on the basal control diet was found to be significantly inferior to that of the children on the supplemented diets, the differences between the values with the three supplemented diets were not significant. However, the general picture from the assessment again indicated the supplementary efficiency of the leaf protein to be greatest followed by that of lysine and sesame flour in that order, further corroborating the evidence obtained from the growth measurements.

The mean values for $\mathrm{N}$ balance and for apparent digestibility of $\mathrm{N}$ in the different diets, determined about the middle of the feeding trial, are presented in Table 6. $\mathrm{N}$ retention in the children in the control group was significantly lower than in the other groups, and although the $\mathrm{N}$ retention values increased in a progressive order in children on the diets supplemented with lysine, sesame and leaf protein, the differences between them were not significant. The apparent digestibility value for the control group was again lowest, that for the lysine group higher than that for the control, but lower than those for the other two supplemented groups; between the values for the groups supplemented with leaf protein and sesame flour there was no significant difference.

The significance of an improvement in the apparent digestibility of the basal diet on supplementation with lysine alone is not clear. The improvements in the diets 
supplemented with leaf protein and sesame flour were evidently because these proteinrich supplements were more digestible than the basal ragi diet. A lack of significant difference between $\mathrm{N}$ retention with the three supplemented diets reflected a more or less equally efficient utilization of the absorbed N. However, the better digestion of leaf-protein and of the protein of the sesame flour supplement, compared to that of the lysine supplement led also to absorption of greater amounts of amino acids other than lysine.

Table 4. Mean physical and chemical measurements in the children at the start and end of the feeding trial with ragi diets with various supplements

(Twenty children in each group)

\begin{tabular}{|c|c|c|c|c|c|c|c|c|c|}
\hline \multirow{2}{*}{$\begin{array}{l}\text { Group } \\
\text { no. }\end{array}$} & \multirow{2}{*}{$\begin{array}{l}\text { Supplement } \\
\text { to diet }\end{array}$} & \multicolumn{2}{|c|}{$\begin{array}{l}\text { Height } \\
(\mathrm{cm})\end{array}$} & \multicolumn{2}{|c|}{$\begin{array}{l}\text { Weight } \\
(\mathrm{kg})\end{array}$} & \multicolumn{2}{|c|}{$\begin{array}{l}\text { Haemoglobin } \\
\qquad(\mathrm{g} / 100 \mathrm{ml})\end{array}$} & \multicolumn{2}{|c|}{$\begin{array}{l}\text { Red blood cell count } \\
\left(\mathrm{I}^{-8} / \mathrm{mm}^{3}\right)\end{array}$} \\
\hline & & Initial & Increase & Initial & Increase & Initial & Increase & Initial & Increase \\
\hline $\mathbf{I}$ & None (control) & $125 \cdot 1$ & $2 \cdot 20$ & $22 \cdot 7$ & 0. & $11 \cdot 83$ & 0.29 & 4.83 & 0.06 \\
\hline 2 & Lysine & 125.5 & $4 \cdot 25$ & 22.7 & 1.05 & $\times 169$ & 0.64 & $4 \cdot 42$ & 0.22 \\
\hline 3 & Leaf protein & $125 \cdot 2$ & $4 \cdot 84$ & $22 \cdot 7$ & $1 \cdot 28$ & $11 \cdot 59$ & 0.87 & $4 \cdot 35$ & 0.23 \\
\hline 4 & $\begin{array}{l}\text { Sesame flour } \\
\text { SEM }(57 \mathrm{df})^{*}\end{array}$ & $125{ }^{\circ} 0$ & $\begin{array}{l}3.5 I \\
0.11\end{array}$ & $22 \cdot 7$ & $\begin{array}{l}0.86 \\
0.04\end{array}$ & II. 82 & $\begin{array}{l}0.73 \\
0.09\end{array}$ & $4 \cdot 36$ & $\begin{array}{l}0.19 \\
0.02\end{array}$ \\
\hline
\end{tabular}

* Standard error of dietary mean values from the analysis of variance.

Table 5. Changes in the general nutritional status* of the children at the end of the feeding trial with ragi diets with various supplements

(Twenty children in each group)

$\begin{array}{clccc}\begin{array}{c}\text { Group } \\ \text { no. }\end{array} & \begin{array}{c}\text { Supplement } \\ \text { to diet }\end{array} & \begin{array}{c}\text { No. } \\ \text { improved }\end{array} & \begin{array}{c}\text { No. } \\ \text { stationary }\end{array} & \begin{array}{c}\text { No. } \\ \text { deteriorated }\end{array} \\ \text { I } & \text { None (control) } & 3 & \text { I I } & 6 \\ 2 & \text { Lysine } & \text { II } & 9 & 0 \\ 3 & \text { Leaf protein } & \text { I3 } & 7 & 0 \\ 4 & \text { Sesame flour } & 8 & \text { I I } & \text { I }\end{array}$

* Assessed according to a score card by Indian Council of Medical Research-Nutrition Advisory Committee (ICMR-NAC, 1948).

Table 6. Results of a nitrogen metabolism study carried out about 3 months after the beginning of the feeding trial with six paired children from four groups given ragi diets with various supplements

\begin{tabular}{|c|c|c|c|c|c|c|c|}
\hline \multirow{3}{*}{$\begin{array}{c}\text { Group } \\
\text { no. }\end{array}$} & \multirow[b]{3}{*}{ Supplement to diet } & \multicolumn{4}{|c|}{$N$ excreted } & \multirow{2}{*}{$\underset{\text { balance }}{\mathrm{N}}$} & \multirow{3}{*}{$\begin{array}{l}\text { Apparent } \\
\text { digesti- } \\
\text { bility } \\
(\%)\end{array}$} \\
\hline & & $\mathbf{N}$ intake & Urinary & Faecal & Total & & \\
\hline & & \multicolumn{5}{|c|}{ (g/child day) } & \\
\hline $\mathbf{I}$ & None (control) & $6 \cdot 10$ & $2 \cdot 61$ & $2 \cdot 74$ & $5 \cdot 35$ & 0.76 & $55 \cdot 1$ \\
\hline 2 & Lysine & $6 \cdot 32$ & $2 \cdot 30$ & $2 \cdot 52$ & $4 \cdot 82$ & $1 \cdot 50$ & 60.2 \\
\hline 3 & Leaf protein & $7 \cdot 75$ & $3 \cdot 23$ & $2 \cdot 63$ & $5 \cdot 86$ & $I \cdot 89$ & $66 \cdot 0$ \\
\hline \multirow[t]{2}{*}{4} & Sesame flour & $7 \cdot 83$ & $3 \cdot 43$ & $2 \cdot 79$ & $6 \cdot 22$ & $x \cdot 6 r$ & $64: 4$ \\
\hline & & \multicolumn{4}{|c|}{ SEM (I $5 \mathrm{df}) *$} & 0.15 & $i \cdot 2$ \\
\hline
\end{tabular}

* Standard error of dietary mean values from analysis of variance.

With respect to the requirements of the children, all diets were low in calories (Table 3 ). The basal control ragi diet and that supplemented with lysine were low in protein also. 
Subrahmanyan et al. (I955) have shown an apparent digestibility of protein of only $50 \%$ in diets based on ragi, with a pattern similar to that used in the present experiments. Our results also showed a similar digestibility of protein in the basal ragi diet. The low digestibility of the protein reduced the amount of lysine available, which otherwise appeared to be adequate from the analyses (Table 3). Supplementation of such a diet with lysine alone improved its nutritive value. The supplementary effects of lysine in ragi diets are similar to those observed in sorghum diets (Doraiswamy, Subramanya Raj Urs, Venkat Rao, Swaminathan \& Parpia, 1968).

The best growth responses were obtained with the diets supplemented with leaf protein, because it supplied both lysine and additional protein. The sesame flour also supplied additional protein, but only about half the amount of lysine of the other two supplements and a consequently smaller growth response.

In a recent investigation on the supplementary effects of lysine on diets deficient in calories, vitamins and minerals, no positive responses were observed in rats with diets based on either wheat or rice (K. C. Pant, A. Bailur \& S. Chinoy, I968, unpublished). In our studies on supplementation of protein-deficient rice diets with leaf protein, we have earlier reported improvements in rats even when the diet was inadequate in vitamins and minerals, and still greater improvements when the diet was adequate in this respect (Shurpalekar et al. 1966). Results of the 6-month-long feeding trials with children showed the superiority of leaf protein over lysine as a supplement. This was evidently due to the increase in the quantity of protein in the diet and improvements in its quality, including adequacy of lysine.

The investigations were supported in part by a grant from the NIH, US Public Health Services through PL -480 funds. The authors wish to thank Dr M. Swaminathan for his keen interest and suggestions in the work, Miss D. Rajalakshmi and $\mathrm{Mr}$ A. N. Sankaran for statistical analysis, Mr M. J. Devaraj for preparing leaf protein, the Micro-Assay Unit of the Institute for lysine estimations and Miss S. Philomena for technical assistance.

\section{REFERENCES}

Balasubramanian, S. C., Ramachandran, M., Viswanatha, T. \& De, S. S. (1957). Indian f. med. Res. 45,623 .

Barton-Wright, B. C. (1952). The Microbiological Assay of the Vitamin B-complex and Amino Acids. London: Sir Isaac Pitman \& Sons Ltd.

Davys, M. N. G. \& Pirie, N. W. (1963). F. agric. Engng Res. 6, 7r.

Doraiswamy, T. R., Parthasarathy, H. N., Tasker, P. K., Sankaran, A. N., Rajagopalan, R., Swaminathan, M., Sreenivasan, A. \& Subrahmanyan, V. (1962). Fd Sci. II, I86.

Doraiswamy, T. R., Subramanya Raj Urs, T. S., Venkat Rao, S., Swaminathan, M. \& Parpia, H. A. B. (1968). F. Nutr. Diet. 5, 19r.

ICMR-NAC (1944). Report of the Scientific Advisory Board for the Year 1944. New Delhi: Indian Council of Medical Research.

ICMR-NAC (1948). Recommendations on the Nutritional Assessment Schedules. New Delhi: Indian Council of Medical Research.

Kurien, P. P., Narayanarao, M., Swaminathan, M. \& Subrahmanyan, V. (1960). Br. F. Nutr. 14, 339.

Morrison, J. E. \& Pirie, N. W. (1961). F. Sci. Fd Agric. 12, I.

Nakagawa, I., Takahashi, T. Suzuki, T. \& Kobayashi, K. (1962). F. Nutr. 77, 6r. 
Pirie, N. W. (1966) Science, N.Y. 152, I 70x.

Shurpalekar, K. S., Singh, N. \& Sunderavalli, O. E. (1966). Int. Congr. Nutr. vir. Hamburg p. 285. Singh, N. (1966). Int. Congr. Fd Sci. Tech. I. Warsaw (Abstracts) p. 19.

Subrahmanyan, V., Narayanarao, M., Ramarao, G. \& Swaminathan, M. (1955). Br. F. Nutr. 9, 350. Tasker, P. K., Doraiswamy, T. R., Narayanarao, M., Swaminathan, M., Sreenivasan, A. \& Subrahmanyan, V. (1962). Br. $\mathcal{F}$. Nutr. 16, 361.

Venkat Rao, S., Joseph, A. A., Swaminathan, M. \& Parpia, H. A. B. (1964). F. Nutr. Diet. 1, I92. 